\title{
Level Kognitif Literasi Berbantuan Explosion Box Sastra terhadap Kemampuan Menemukan dan Memahami Konsep Moral Siswa Kelas IV SD
}

\author{
Fitriya Nur Rahmah ${ }^{1}$, Dedi Kuswandi ${ }^{2}$, Alif Mudiono ${ }^{3}$ \\ ${ }^{1}$ Pendidikan Dasar-Universitas Negeri Malang \\ ${ }^{2}$ Teknologi Pembelajaran-Universitas Negeri Malang \\ ${ }^{3}$ Pendidikan Guru Sekolah Dasar-Universitas Negeri Malang
}

\begin{tabular}{|c|c|}
\hline INFO ARTIKEL & ABSTRAK \\
\hline Riwayat Artikel: & $\begin{array}{l}\text { Abstract: This study prove the influence of experiential-assisted cognition on moral } \\
\text { reasoning. Used quantitative approach, quasi experiment type, pretest-posttest control }\end{array}$ \\
\hline Diterima: 01-03-2019 & group design. The results showed there was influence on the level of cognitive literacy \\
\hline Disetujui: 21-04-2019 & based on the explosion box literature's four PIRLS rating scale on the ability to \\
\hline Kata kunci: & $\begin{array}{l}\text { understand in both groups of trials and found moral concepts in the control group } \\
\text { (Pillai's Trace test significance value was smaller than alpha 5\%). The ex box literary }\end{array}$ \\
\hline $\begin{array}{l}\text { explosion box; } \\
\text { cognitive level; } \\
\text { literacy; } \\
\text { literature; }\end{array}$ & $\begin{array}{l}\text { product as Gerakan Literasi Sekolah innovation to develop personal literate character } \\
\text { through literacy reading which uniquely and interestingly packaged so it trains and } \\
\text { improves the cognitive level of literacy and moral reasoning experience of fourth grade } \\
\text { students. }\end{array}$ \\
\hline
\end{tabular}

\begin{abstract}
Abstrak: Studi ini membuktikan pengaruh kognisi berbantuan pengalaman dan lingkungan terhadap penalaran moral. Penelitian menggunakan pendekatan kuantitatif jenis eksperimen semu pretest-posttest control group design. Hasil menunjukkan terdapat pengaruh level kognitif literasi berdasarkan empat skala penilaian PIRLS berbantuan explosion box sastra terhadap kemampuan memahami pada kedua kelompok uji coba dan menemukan konsep moral pada kelompok kontrol (nilai signifikansi uji Pillai's Trace lebih kecil dari alpha 5\%). Produk ex box sastra menjadi inovasi Gerakan Literasi Sekolah untuk menumbuhkembangkan pribadi literat berbudi pekerti melalui bacaan literasi yang dikemas secara unik dan menarik sehingga melatih dan meningkatkan level kognitif literasi dan pengalaman penalaran moral siswa kelas IV.
\end{abstract}

\author{
Alamat Korespondensi: \\ Fitriya Nur Rahmah \\ Pendidikan Dasar \\ Universitas Negeri Malang \\ Jalan Semarang 5 Malang \\ E-mail: fitsweet.fs@gmail.com
}

Kemampuan kognitif seseorang tentang moralitas memengaruhi kompetensi moral seseorang. Kompetensi moral meliputi kemampuan bertindak, pengetahuan mengonstruk perilaku, keterampilan, kesadaran tentang aturan dan pengaturan moral. Sebagaimana teori kognitif sosial yang mengasumsikan bahwa kognisi menjadi jembatan antara pengalaman dengan lingkungan dan perilaku moral (Dworetzky, 1990; Santrock, 2007; Schunk, 2012). Bandura (2004) juga percaya bahwa perkembangan moral akan dimengerti lebih baik dengan cara mempertimbangkan kombinasi faktor sosial dan kognitif (Santrock, 2007;).

Berbeda dengan teori kognitif sosial, menurut teori perkembangan moral kemajuan dalam perkembangan kognitif anak tidak menentukan perkembangan penalaran moral. Kohlberg percaya bahwa penalaran moral mencerminkan pengalaman anak dalam menghadapi pertanyaan moral dan kritik moral (Dworetzky, 1990; (Lourenço, 2014); (Maxwell, 2010); Santrock, 2007). Pengalaman tersebut didukung adanya interaksi dengan teman sebaya yang mampu mengubah penalaran moral. Perubahan dalam cara berpikir moral ini menurut Piaget terjadi saat anak berkembang mereka dapat berpikir secara lebih rumit mengenai masalah sosial terutama terhadap kemungkinan dan kondisi kerja sama (Santrock, 2007). Pemahaman sosial terjadi melalui saling memberi dan menerima dalam hubungan dengan teman sebaya. Di dalam peer group (kelompok sebaya), rencana dalam penalaran moral biasanya dikoordinasikan dan dirundingkan, dan perbedaan pendapat dibahas dan pada akhirnya bisa diselesaikan.

Penalaran moral dapat dipengaruhi oleh proses berpikir. Tingkatan berpikir literasi berdasarkan PIRLS meliputi level low, intermediate, high, advanced. Secara logis, semakin tinggi level kognitif literasi siswa maka kemampuan memahami konsep moral semakin meningkat. Jika siswa mampu memahami, maka siswa dapat menemukan konsep moral pada bacaan. Kompetensi moral tersebut diperoleh manusia melalui keterampilan membaca. Melalui kegiatan membaca, manusia memiliki 
kemampuan untuk memperoleh informasi-informasi yang diperlukannya (Ditjen Dikdasmen, 2016b; Faizah, dkk., 2016). Semakin banyak membaca, maka banyak informasi dan pengetahuan yang akan diperoleh si pembaca. Sebaliknya, semakin sedikit membaca tentu berakibat pada sedikitnya pengetahuan yang diperoleh si pembaca.

Masyarakat Indonesia saat ini termasuk dalam kategori sedikit membaca. Rendahnya minat baca masyarakat Indonesia; rendahnya pemahaman membaca, matematika, dan sains para siswa sekolah di Indonesia pada tingkat sekolah menengah usia 15 tahun; dan rendahnya kemampuan literasi membaca siswa kelas IV SD ((Fajrin, Zainuddin, \& Gipayana, 2017); Kalida \& Mursyid, 2015; Mullis, dkk., 2012; OECD, 2016; (Puspita, Sunendar, Musthafa, \& Agung, 2017); Subkhan, 2016; (Triatma, 2016); (Wahyuni, 2019)) menunjukkan rendahnya capaian Indonesia terhadap keterampilan membaca abad 21. Menurut Ditjen Dikdasmen (2016a), meliputi tuntutan kemampuan mengakses; memahami informasi secara analitis, kritis, dan reflektif; menggunakannya secara cerdas. Hal tersebut menimbulkan kekhawatiran pemerintah Indonesia terhadap rendahnya keterampilan membaca yang berdampak pada rendahnya pengetahuan para siswa yang ada di seluruh Indonesia. Rendahnya pengetahuan tentu akan berdampak pada rendahnya kemampuan berkompetisi ketika hidup berdampingan dengan bangsa lain di dunia.

Merespon rendahnya hasil penelitian tersebut, pemerintah Indonesia menerbitkan Permendikbud RI Nomor 23 tahun 2015 tentang gerakan Penumbuhan Budi Pekerti yang diisi dengan kegiatan Gerakan Literasi Sekolah. Sejak diundangkan, lazimnya sudah menjadi gerakan bersama di semua sekolah sasaran. Meskipun saat ini upaya tersebut sedang dilakukan secara bertahap dan berkelanjutan, tetapi masih ditemui penurunan kualitas moral, seperti berkurangnya tata krama antara anak muda dengan orangtua yang mulai tidak diacuhkan, berbicara tidak sopan dengan teman orangtua, tindak tanduk yang kurang senonoh di tempat umum, dan perkelahian antar teman sebaya. Munculnya ragam permasalahan penyimpangan moral menyebabkan dunia pendidikan menjadi sorotan utama. Apakah benar melalui Gerakan Literasi Sekolah menggunakan bahan pustaka non pelajaran khususnya sastra yang sarat dengan nilai kehidupan, siswa akan dilatih dan dibimbing untuk membentuk pengetahuan tentang nilai moral yang terkandung pada bacaan literasi yang dimaksud secara mandiri? Apakah siswa kelas IV SD dapat memahami nilai moral melalui bacaan? Bagaimana capaian kemampuan literasi siswa kelas IV SD tersebut? Tentu hal tersebut menarik untuk dikaji.

Peneliti tertarik melanjutkan studi tentang capaian Gerakan Literasi Sekolah. Fokus menjelaskan pengaruh level kognitif literasi terhadap kemampuan siswa kelas IV SD dalam memahami dan menemukan konsep moral pada bacaan sastra. Dengan berbasis PIRLS peneliti mengembangkan instrumen asesmen literasi berbantuan explosion box untuk diuji pengaruhnya terhadap kemampuan membaca pemahaman konsep moral pada bacaan sastra.

Explosion box (ex box) merupakan media tiga dimensi yang lebih umum digunakan sebagai kotak kejutan untuk hadiah istimewa di hari spesial. Kejutan dalam kotak tersebut memuat gambar, foto, ungkapan, atau kenangan yang dikemas dalam kotak dengan tampilan yang unik. Lebih dari sekedar kejutan dan hadiah, dewasa ini beberapa akademisi telah meneliti dan mengembangkan explosion box sebagai media edukasi. Explosion box merupakan media cetak yang berisi tulisan, teks, atau gambar telah berhasil membuktikan bahwa media tersebut mampu meningkatkan literasi siswa kelas VII SMPN 26 Surabaya (Waladiyah, 2018). Demikian pula dengan produk media pembelajaran explosion history box oleh Febriana (2018) yang layak digunakan dan dapat meningkatkan motivasi belajar siswa kelas X SMK Negeri 7 Malang. (Nasriya, 2018) Ex box juga dapat digunakan sebagai media pembelajaran untuk mempermudah proses pembelajaran materi komponen ekosistem di kelas $\mathrm{V}$ MI Perwanida Blitar.

\section{METODE}

Penelitian ini menggunakan eksperimen kuasi dengan rancangan pretest-posttest control group design untuk membandingkan dua kelompok uji coba yang terdiri dari kelas eksperimen dan kelas kontrol. Pada kelas eksperimen diberikan perlakuan kegiatan literasi dengan bantuan explosion box untuk mengerjakan tes berdasarkan level kognitif literasi (low, intermediate, high, dan advanced). Sementara itu, pada kelas kontrol kegiatan literasi dilakukan secara konvensional tanpa bantuan explosion box. Pada masing-masing kelas akan diuji kemampuan sebelum perlakuan dan setelah perlakuan diberikan. Data berupa skor tes kemampuan memahami dan menemukan konsep moral pada bacaan sastra berbasis PIRLS. Penelitian dilakukan pada kelas yang sudah terstruktur oleh sekolah. Subjek penelitian tidak dipilih secara random, tetapi secara cluster random sampling karena tidak memungkinkan untuk mengacak kelas yang sudah ada. Oleh sebab itu, pendekatan yang digunakan yaitu penelitian kuantitatif dengan desain eksperimen semu atau quasi experimental design, jenis pretest-posttest control group design (Arikunto, 2013; Leech, dkk., 2005).

\section{HASIL}

Pengumpulan data menggunakan instrumen tes tertulis berbasis teks sastra dengan judul "Masakan Ayah" yang telah diolah peneliti sesuai tingkat keterbacaan usia siswa kelas IV SD/MI. Tes tertulis dibagi menjadi dua bagian, yaitu (1) mengetahui tingkat pemahaman siswa tentang konsep moral yang ada pada materi tes dan (2) mengetahui tingkat kemampuan siswa dalam menemukan konsep moral pada bacaan. Pertama, tes dikembangkan berdasarkan draf konstruk instrumen asesmen literasi siswa dari PIRLS (Fajrin, 2017; Mullis, dkk., 2012; (Musfiroh, 2016)). Terdapat 10 soal pada tes pertama terdiri dari empat tingkatan kognitif berupa soal objektif dan uraian, dengan rincian: dua low, tiga intermediate, dan satu (soal pilihan tunggal dan dua soal uraian level high; dua soal uraian level advanced. 
Kedua, untuk mengetahui tingkat kemampuan siswa dalam menemukan konsep moral pada bacaan. Setelah membaca dan mengerjakan soal, siswa diminta menuliskan konsep moral yang ditemukan disertai tokoh yang berperan dan bukti pada teks bacaan "Masakan Ayah".

Pretest pada kelas eksperimen dilaksanakan sebelum kegiatan literasi dengan bantuan explosion box. Sementara pretest pada kelas kontrol berlangsung sebelum kegiatan literasi secara konvensional sesuai pedoman GLS. Selanjutnya kegiatan literasi dilakukan sesuai dengan perlakuan masing-masing kelas.

Kelas eksperimen melakukan kegiatan literasi berbantuan explosion box. Pelaksanaan diawali dengan pengelompokan siswa yang terdiri dari empat siswa tiap satu kelompok. Kemudian guru memberikan satu explosion box untuk masing-masing kelompok. Setelah itu guru menjelasan petunjuk penggunaan explosion box kepada siswa. Selanjutnya siswa membaca dalam hati menggunakan explosion box untuk kegiatan literasi dan mengerjakan soal posttest selama 30 menit. Kegiatan diakhiri dengan refleksi guru dan siswa selama 5-10 menit.

Kegiatan literasi pada kelas kontrol dilakukan secara konvensional. Secara klasikal guru dan siswa melakukan kegiatan diskusi dan tanya jawab tentang bacaan sastra "Masakan Ayah" dan konsep moral yang termuat di dalamnya. Setelah itu masing-masing siswa membaca senyap buku bacaan sastra yang telah dibagikan untuk mengerjakan soal posttest selama 30 menit. Kemudian selama 5-10 menit guru dan siswa merefleksi kegiatan

Pelaksanaan penelitian diikuti oleh 233 siswa kelas IV. Berdasarkan data kelompok kontrol dan eksperimen hasil pretest dan posttest diketahui skor rata-rata kemampuan memahami dan menemukan konsep moral kelompok kontrol lebih tinggi daripada kelompok eksperimen sesuai tabel 1.

Tabel 1. Kemampuan Memahami dan Menemukan Konsep Moral

\begin{tabular}{lrrrrrrr}
\hline \multirow{2}{*}{$\begin{array}{l}\text { Kelompok } \\
\text { Subjek }\end{array}$} & \multirow{2}{*}{$\mathbf{N}$} & \multicolumn{6}{c}{ Skor rata-rata } \\
\cline { 3 - 7 } & & \multicolumn{4}{c}{ Memahami } & \multicolumn{3}{c}{ Menemukan } \\
\cline { 3 - 7 } & & Pre & Post & Selisih & Pre & Post & Selisih \\
\hline Kontrol (K) & 36 & $67, \mathbf{8 8}$ & $\mathbf{6 9 , 2 9}$ & $\mathbf{1 , 4 1}$ & $\mathbf{1 7 , 2 6}$ & $\mathbf{3 8 , 9 9}$ & $\mathbf{2 1 , 7 3}$ \\
\hline IVB SDN Lesanpuro 4 Kota Malang & 69,44 & 2,5 & 24,36 & 52,00 & 27,64 \\
IVB SDN Percobaan 1 Kota Malang & 33 & 68,18 & 72,12 & 3,94 & 9,39 & 37,03 & 27,64 \\
IVB SDN Kauman 1 Kota Malang & 30 & 68,67 & 66,00 & $-2,67$ & 17,40 & 25,53 & 8,13 \\
\hline Eksperimen (E) & & $\mathbf{6 7 , 0 9}$ & $\mathbf{6 6 , 8 7}$ & $\mathbf{- 0 , 2 2}$ & $\mathbf{1 2 , 4 2}$ & $\mathbf{3 7 , 4 0}$ & $\mathbf{2 4 , 9 8}$ \\
\hline IV SDN Kedungkandang 1 Kota Malang & 28 & 64,29 & 66,79 & 2,5 & 12,07 & 11,43 & $-0,64$ \\
IVA SDN Lesanpuro 4 Kota Malang & 40 & 70,00 & 70,00 & 0 & 16,53 & 62,38 & 45,85 \\
IVA SDN Percobaan 1 Kota Malang & 36 & 64,17 & 61,11 & $-3,06$ & 9,61 & 5,44 & $-4,17$ \\
IVA SDN Kauman 1 Kota Malang & 30 & 69,33 & 69,67 & 0,34 & 10,63 & $\mathbf{6 6 , 6 7}$ & 56,04 \\
\hline Selisih (K-E) & & $\mathbf{0 , 7 9}$ & $\mathbf{2 , 4 2}$ & & $\mathbf{4 , 8 4}$ & $\mathbf{1 , 5 9}$ \\
\hline
\end{tabular}

Kemampuan awal memahami konsep moral kelompok kontrol bedasarkan tabel 4.21 menunjukkan skor rata-rata 67,88. Beda 0,79 skor rata-rata kelompok eksperimen yaitu 67,09. Sementara skor rata-rata kemampuan akhir kelompok kontrol 69,29 yang menunjukkan peningkatan sebesar 1,41. Kelompok eksperimen mengalami sedikit penurunan pada tes akhir dengan skor rata-rata 66,87 selisih 0,22 dari skor awal. Sehingga beda kemampuan akhir kedua kelompok menjadi 2,42. Subjek yang mengalami peningkatan kemampuan memahami konsep moral yaitu dua subjek kelompok kontrol (IVB SDN Lesanpuro 4 Kota Malang dan IVB SDN Percobaan 1 Kota Malang) dan dua subjek kelompok eksperimen (IV SDN Kedungkandang 1 Kota Malang dan IVA SDN Kauman 1 Kota Malang). Subjek dari kelas eksperimen IVA SDN Lesanpuro 4 Kota Malang konstan. Sementara satu subjek dari masing-masing kelompok kontrol dan eksperimen mengalami penurunan yaitu IVB SDN Kauman 1 Kota Malang dan IVA SDN Percobaan 1 Kota Malang.

Skor rata-rata kemampuan awal menemukan konsep moral kelompok kontrol diketahui 17,26. Sementara kelompok eksperimen 12,42. Selisih awal kedua kelompok 4,84. Kemampuan akhir kelompok kontrol meningkat 21,73 sehingga skor rata-rata menjadi 38,99. Kelompok eksperimen juga mengalami peningkatan sebesar 24,98 sehingga skor rata-rata akhir 37,40. Dengan demikian selisih skor rata-rata kemampuan akhir kedua kelompok 1,5. Kemampuan menemukan konsep moral meningkat pada subjek kelompok kontrol (IVB SDN Lesanpuro 4 Kota Malang, IVB SDN Percobaan 1 Kota Malang, IVB SDN Kauman 1 Kota Malang) dan dua subjek kelompok eksperimen (IVA SDN Lesanpuro 4 Kota Malang dan IVA SDN Kauman 1 Kota Malang). Sementara dua subjek dari kelompok eksperimen mengalami penurunan, yaitu IV SDN Kedungkandang 1 Kota Malang dan IVA SDN Percobaan 1 Kota Malang.

\section{PEMBAHASAN}

Kegiatan literasi dengan menggunakan bacaan sastra untuk penalaran moral sesuai dengan penelitian terdahulu oleh (Almerico, 2014); (Hasanah, 2012); Kohlberg (1969) dalam Santrock (2007); (Mardiah, Suwignyo, \& Kuswandi, 2016); (Permata, Wahyono, \& Wardoyo, 2017); (Prayoga, Suwignyo, \& Harsiati, 2017); (Ridwan \& Mudiono, 2017); (Sa'adah, 2016); Sholihah (2018); (Wachidah, Suwignyo, \& Widiati, 2017); (Wulananda, Saryono, \& Suwignyo, 2016). Data penelitian kemudian dianalisis menggunakan Mulivariate Analysis of Variance dengan program SPSS. Uji ini membandingkan rata-rata 
skor variabel memahami konsep moral dan variabel menemukan konsep moral antara kelas kontrol dan eksperimen (bantuan explosion box) secara simultan. Empat uji statistik yang digunakan, yaitu Pillai's Trace, Wilk's Lambda, Hotelling's Trace, dan Roy's Largest Root. Pengujian data awal diperoleh nilai signifikansi lebih kecil dari alpha 5\% $(0.001<0.050)$, secara serempak terdapat perbedaan signifikan kedua kelompok pada variabel memahami dan menemukan.

Uji univariat kemudian dilakukan untuk menguji variabel secara parsial atau masing-masing perlakuan. Hasil pengujian variabel pertama nilai signifikansi lebih besar dari alpha 5\% (0.691 > 0.050), terdapat perbedaan yang tidak signifikan pada pengujian variabel memahami konsep moral. Dengan kata lain, skor pretest variabel memahami konsep moral relatif sama antara kelas kontrol dan eksperimen.

Pada uji variabel kedua nilai signifikansi lebih besar dari alpha 5\% $(0.000<0.050)$, ada perbedaan yang signifikan pada pengujian variabel menemukan konsep moral. Terlihat dari rata-rata skor pretest variabel menemukan konsep moral kelas kontrol lebih tinggi dari skor kelas eksperimen.

Hasil pengujian manova data akhir nilai signifikansi lebih besar dari alpha 5\% $(0.473>0.050)$, secara serempak terdapat perbedaan yang tidak signifikan antara kedua kelompok kelas pada variabel memahami konsep moral dan variabel menemukan konsep moral, yaitu kelas kontrol dan eksperimen (bantuan explosion box).

Berdasarkan uji parsial rata-rata skor akhir variabel memahami konsep moral dan variabel menemukan konsep moral antara kelas kontrol dan eksperimen (bantuan explosion box) diperoleh nilai signifikansi lebih besar dari alpha $5 \%$ (0.225 > 0.050), perbedaan tidak signifikan pada pengujian variabel memahami konsep moral. Atau dengan kata lain, skor posttest variabel memahami konsep moral relatif sama antara kelas kontrol dan eksperimen (bantuan explosion box).

Pada pengujian variabel menemukan konsep moral untuk perbandingan antara siswa antar kelas, didapatkan nilai signifikansi lebih besar dari alpha $5 \%(0.724$ > 0.050) maka dapat dikatakan bahwa terdapat perbedaan yang tidak signifikan pada pengujian variabel menemukan konsep moral. Atau dengan kata lain, skor posttest variabel menemukan konsep moral relatif sama antara kelas kontrol dan eksperimen (bantuan explosion box).

Kemampuan berpikir moral siswa mengalami peningkatan dapat disebabkan oleh faktor waktu, bacaan, pelaksanaan, dan motivasi siswa. Waktu siswa berliterasi untuk membaca dalam hati dan mengerjakan tes secara mandiri lebih cukup dari ketentuan 15 menit (Permendikbud RI No.23 tahun 2015; Ditjen Dikdasmen, 2016; Faizah, dkk., 2016). Bacaan sastra dipilih sesuai dengan kehidupan di sekitar siswa yang memuat kebiasaan, sikap, dan perilaku baik untuk diteladani (Darmadi, 2009; Noor, 2011; Wicaksono, 2014); tampilan menarik khususnya pada kelas eksperimen yang dikemas dalam kotak kejutan; setiap siswa pada kelas kontrol mendapatkan satu buku sehingga proses penalaran moral tidak terganggu atau terpengaruhi oleh siswa lain.

Pelaksanaan literasi berbeda dari Gerakan Literasi Sekolah yang diterapkan sekolah subjek penelitian. Kegiatan literasi yang dilakukan sekolah, yaitu pembiasaan membaca dan menulis, menyediakan sarana dan prasarana, membuat lingkungan kaya teks, memilih buku untuk literasi, melibatkan publik; (2) pengembangan: membaca mandiri, melakukan diskusi tanya jawab, mencatat bahan bacaan, pemanfaatan lingkungan literasi berupa perpustakaan; dan (3) pembelajaran: membuat lembar karya berbasis teks dan memanfaatkan perpustakaan saat literasi dalam pembelajaran (Aji, 2018; Febriyanto, 2018; (Hidayat, Basuki, \& Akbar, 2018); (Khotimah, Akbar, \& Sa'dijah, 2018)). Siswa sangat antusias mengikuti kegiatan literasi dari awal hingga selesai. Pada saat diskusi klasikal pada kelas kontrol tentang isi bacaan dan konsep moral yang termuat siswa aktif melakukan tanya jawab yang difasilitasi guru. Siswa berliterasi dengan waktu lebih dari cukup pada kelas kontrol, kegiatan menggunakan ex box secara kelompok pada kelas eksperimen, bacaan yang baru, unik, serta menarik sehingga meningkatkan motivasi untuk mengerjakan soal (Jacobs, 2008); (Solihah, Santoso, \& Mudiono, 2018).

Faktor kognisi pun memengaruhi kemampuan siswa. Menurut teori kognitif sosial, kognisi menjembatani pengalaman dengan lingkungan dan perilaku moral (Bandura, 2004; Dworetzky, 1990; Santrock, 2007; Schunk, 2012). Proses berpikir seseorang tentang moralitas menjadi penghubung antara pengalaman siswa berliterasi (membaca dan mengerjakan soal) dengan lingkungan (bacaan sastra, media $e x$ box, pelaksanaan literasi secara mandiri dan kelompok) dan perilaku moral (teladan moral dari tokoh dalam bacaan sastra). Kemampuan memahami dan menemukan konsep moral pada bacaan sastra tidak terjadi secara otomatis karena membaca adalah proses berpikir (Gipayana, 2010; Harsiati, 2011).

Meningkatnya kemampuan penalaran moral akibat dari proses berpikir siswa yang meningkat dari rendah menjadi level yang lebih tinggi. Level low menjadi intermediate atau high maupun advanced. Secara logis, semakin tinggi level kognitif literasi siswa maka kemampuan memahami konsep moral semakin meningkat. Jika siswa mampu memahami, maka siswa dapat menemukan konsep moral pada bacaan. Asumsi tersebut berlaku pada subjek berlevel kognitif literasi tinggi hingga mahir yang mampu memahami dan menemukan konsep moral. Namun, keyakinan tersebut tidak berlaku pada subjek berlevel kognitif literasi tinggi atau mahir yang berkemampuan rendah dalam menemukan konsep. Asumsi tersebut sesuai dengan pendapat Kohlberg bahwa kemajuan dalam perkembangan kognitif anak tidak menentukan perkembangan penalaran moral ((Lourenço, 2014); (Maxwell, 2010); Santrock, 2007). Penalaran moral mencerminkan pengalaman anak dalam menghadapi pertanyaan moral dan kritik moral.

Pada subjek penelitian yang mengalami penurunan kemampuan bisa diakibatkan oleh kognisi siswa rendah khususnya pada kelas yang terdapat siswa berkebutuhan khusus (Mayer, 1998), lingkungan kurang mendukung (López, 2017), waktu yang dibutuhkan pada kelas eksperimen yang menggunakan ex box masih kurang, sementara pada kelas kontrol pelaksanaan saat siang hari karena menyesuaikan perubahan jadwal dari pihak sekolah. 


\section{SIMPULAN}

Berdasarkan hasil dan pembahasan penelitian ini, terbukti bahwa (1) terdapat pengaruh level kognitif literasi empat skala penilaian PIRLS (Advanced, High, Intermediate, Low) terhadap kemampuan memahami konsep moral siswa kelas IV; (2) ada pengaruh level kognitif literasi berbasis PIRLS terhadap kemampuan menemukan konsep moral pada kelas kontrol. Namun tidak terdapat pengaruh antar variabel pada kelompok eksperimen; (3) level kognitif literasi tanpa bantuan memengaruhi kemampuan memahami dan menemukan konsep moral siswa kelas IV; (4) level kognitif literasi empat kategori berbantuan explosion box sastra berpengaruh terhadap kemampuan memahami dan menemukan konsep moral siswa kelas IV; (5) tidak terdapat perbedaan pengaruh level kognitif literasi antara kelas kontrol yang tidak menggunakan ex box sastra dan kelas eksperimen yang berbantuan media tersebut terhadap kemampuan memahami dan menemukan konsep moral siswa kelas IV. Kedua kelompok memiliki kemampuan akhir relaif sama atau tidak ada beda antara kelas kontrol dan eksperimen. Kemampuan akhir menunjukkan peningkatan signifikan pada kelas eksperimen sehingga mampu mengimbangi kemampuan kelas kontrol yang lebih tinggi di awal.

Pendidik dapat melatih kognisi dan pengalaman penalaran moral untuk meningkatkan, memahami, dan menemukan konsep moral dengan bantuan ex box sastra saat kegiatan literasi. Literasi sekolah sebaiknya dilaksanakan lebih dari 15 menit atau menyesuaikan kebutuhan pelaku literasi dengan kegiatan variatif, tidak selalu membaca-menulis-menghasilkan karya, tetapi lebih memanfaatkan kegiatan individu atau kelompok menggunakan media maupun bacaan literasi yang baru, unik, menarik, dan mengandung nilai kebaikan untuk diteladani sebagai upaya bersama menumbuhkembangkan pribadi literat berbudi pekerti. Untuk mewujudkan hal tersebut, perlu penelitian lebih lanjut tentang (1) cara siswa mempertimbangkan, berpikir, berperilaku, merasakan, dan berkepribadian moral yang melibatkan perubahan penalaran, perasaan, dan perilaku mengenai standar benar dan salah; (2) kompetensi moral yang meliputi kemampuan bertindak, pengetahuan mengonstruk perilaku, keterampilan, kesadaran tentang aturan dan pengaturan moral; (3) hubungan antara kognisi (level kognitif literasi), pengalaman (kegiatan literasi), lingkungan (media/sarana literasi), dan perilaku moral (teladan moral dari kegiatan atau media literasi).

\section{DAFTAR RUJUKAN}

Aji, S. M. W. (2018). Pelaksanaan Gerakan Literasi Sekolah (Studi Multi Situs di SDN Kauman I dan di SDN Percobaan I Kota Malang). Tesis tidak diterbitkan. Universitas Negeri Malang, Malang.

Almerico, G. (2014). Building Character Through Literacy with Children's Literature. Research in Higher Education Journal, $26,1-13$.

Arikunto, S. (2013). Prosedur Penelitian: Suatu Pendekatan Praktik. Jakarta: Rineka Cipta.

Darmadi, H. (2009). Dasar Konsep Pendidikan Moral. Bandung: Alfabeta.

Ditjen Dikdasmen (Direktorat Jenderal Pendidikan Dasar dan Menegah). (2016a). Buku Saku Gerakan Literasi Sekolah: Menumbuhkan Budaya Literai di Sekolah. Jakarta: Kementerian Pendidikan dan Kebudayaan Republik Indonesia. (Online), (http://dikdasmen.kemdikbud.go.id, diakses 15 Desember 2016).

Ditjen Dikdasmen (Direktorat Jenderal Pendidikan Dasar dan Menegah). (2016b). Desain Induk Gerakan Literasi Sekolah: Menumbuhkan Budaya Literai di Sekolah. Jakarta: Kementerian Pendidikan dan Kebudayaan Republik Indonesia. (Online), (http://dikdasmen.kemdikbud.go.id, diakses 15 Desember 2016).

Faizah, D. U., Sufyadi, S., Anggraini, L., Waluyo., Dewayani, S., Muldian, W., Roosaria, D. R. (2016). Panduan Gerakan Literasi Sekolah di Sekolah Dasar. Jakarta: Direktorat Jenderal Pendidikan Dasar dan Menegah Kementerian Pendidikan dan Kebudayaan. (Online), (http://dikdasmen. kemdikbud.go.id), diakses 15 Desember 2016.

Fajrin, N., Zainuddin, M., \& Gipayana, M. (2017). Pembelajaran Keterampilan Membaca. Prosiding TEP \& PDs Transformasi Pendidikan Abad 21, 4(32), 396-401.

Febriana, P. (2018). Pengembangan Media Pembelajaran Explosion History Box pada Materi Masuknya Bangsa Eropa ke Indonesia Kelas X SMK Negeri 7 Malang. Skripsi tidak diterbitkan. Universitas Negeri Malang, Malang.

Febriyanto, D. D. (2018). Implementasi Gerakan Literasi Sekolah di Sekolah Dasar. Tesis tidak diterbitkan. Universitas Negeri Malang, Malang.

Gipayana, M. (2010). Pengajaran Literasi Menulis di SD-MI. Malang: Asah Asih Asuh.

Harsiati, T. (2011). Development of Literacy Test on Critical and Creative Reading for Junior High School Student. Jurnal Evaluasi Pendidikan, 2(1), 84-100. https://doi.org/10.21009/jep.021.07

Hasanah, M. (2012). Model Cerita Fiksi Kontemporer Anak-anak untuk Pengembangan Kemahirwacanaan Siswa Kelas 5 Sekolah Dasar. Litera, 11(1), 98-109.

Hidayat, M., Basuki, I., \& Akbar, S. (2018). Gerakan Literasi Sekolah Dasar. Jurnal Pendidikan: Teori, Penelitian, dan Pengembangan, 3(6), 810-817.

Jacobs, J. (2008). Moral Theory and Moral Psychology. In Dimensions of Moral Theory (pp. 42-73). https://doi.org/10.1002/9780470775899.ch2

Kalida, M., \& Mursyid, M. (2015). Gerakan Literasi Mencerdaskan Negeri. Yogyakarta: Aswaja Perindo.

Khotimah, K., Akbar, S., \& Sa'dijah, C. (2018). Pelaksanaan Gerakan Literasi Sekolah. Jurnal Pendidikan: Teori, Penelitian, dan Pengembangan, 3(11), 1488-1498. 
Leech, N. G., Barrett, K. C., \& Morgan, G. A. 2005. SPSS for intermediate statistics: Use and interpretation, $2^{\text {nd }}$ edition. London: Lawrence Erlbaum Associates.

López, M. (2017). Self-generated Literacy Practices in Disadvantaged Environments in Chile. International Journal of Education and Literacy Studies, 5(1), 29-41. https://doi.org/10.7575/aiac.ijels.v.5n.1p.29

Lourenço, O. (2014). Why be moral? In defense of a Kohlbergian approach. Psychologica, 56, $25-42$. https://doi.org/10.14195/1647-8606_56_2

Mardiah, A., Suwignyo, H., \& Kuswandi, D. (2016). Pengembangan Modul Membaca Intensif Materi Cerita Petualangan Berbasis Saintifik. Jurnal Pendidikan: Teori, Penelitian, dan Pengembangan, 1(6), 1115-1119.

Maxwell, B. (2010). Does ethical theory have a place in post-kohlbergian moral psychology? Educational Theory, 60(2), 167188. https://doi.org/10.1111/j.1741-5446.2010.00352.x

Mayer, R. (1998). Does the Brain Have a Place in Educational Psychology? Educational Psychology Review, 10(4), $389-396$. https://doi.org/10.1023/A:1022837300988

Mullis, I.V.S., Martin, M. O., Foy, P., \& Drucker, K. T. 2012. Progress in International Reading Literacy Study (PIRLS). Amsterdam: International Association for the Evaluation of Educational Achievement (IEA).

Musfiroh, T. (2016). Konstruk Kompetensi Literasi untuk Siswa Sekolah Dasar. Litera, 15(1), 2-5.

Nasriya, T. (2018). The Development of Explosion Box as Learning Media for Teaching Components of Ecosystem at 5th grade MI Perwanida Blitar. Thesis. Islamic Elementary Education Program (Maulana Malik Ibrahim State Islamic University of Malang). Retrieved from http://etheses.uin-malang.ac.id/id/eprint/11820

Noor, R. M. (2011). Pendidikan Karakter Berbasis Sastra. Yogyakarta: Ar-Ruzz Media.

OECD. 2016. Result from PISA. Canada: OECD.

Permata, B., Wahyono, H., \& Wardoyo, C. (2017). Bahan Ajar Berbasis Cerita Untuk. Jurnal Pendidikan: Teori, Penelitian, dan Pengembangan, 2(3), 356-362.

Permendikbud RI Nomor 23 tahun 2015 tentang Penumbuhan Budi Pekerti. 2015. Jakarta: Kementerian Pendidikan dan Kebudayaan Republik Indonesia. (Online), (http://dikdasmen.kemdikbud.go.id, diakses 15 Desember 2016).

Prayoga, R., Suwignyo, H., \& Harsiati, T. (2017). Peningkatan Keterampilan Menulis Cerita Berbantuan Media Buku Cerita Anak. Jurnal Pendidikan: Teori, Penelitian, dan Pengembangan, 2(11), 1498-1503.

Puspita, R., Sunendar, D., Musthafa, B., \& Agung, R. (2017). Improving Students Reading Comprehension Ability Through Integrated Thematic Learning With School Literacy Movement Support. Jurnal Pendidikan Humaniora, 5(3), 99-103. https://doi.org/10.17977/um030v5i32017p099

Ridwan, M., \& Mudiono, A. (2017). Analisis Muatan Nilai-Nilai Karakter Pada Buku Siswa Kelas Iv Sekolah Dasar Tema Indahnya Kebersamaankebersamaan. Wahana Sekolah Dasar (Kajian Teori Dan Praktik Pendidikan), $25(1), 1-7$.

Sa’adah, I. (2016). Nilai-Nilai Moral Pada Bacaan Bahasa Jawa. Prosiding Seminar Nasional KSDP Prodi S1 PGSD "Konstelasi Pendidikan dan Kebudayaan Indonesia Di Era Globalisasi, 269-282.

Santrock, J. W. (2007). Perkembangan Anak: Jilid 2. Jakarta: Penerbit Erlangga.

Schunk, D. H. (2012). Teori Pembelajaran: Sebuah Pendekatan Pendidikan (edisi keenam). Boston, MA: Pearson.

Solihah, F., Santoso, A., \& Mudiono, A. (2018). Studi Penerapan Program Pembiasaan Membaca di Sekolah Dasar. Jurnal Pendidikan: Teori, Penelitian, dan Pengembangan, 3(3), 382-397.

Subkhan, E. (2016). Pendidikan Kritis Kritik atas Praksis Neoliberalisasi dan Standardisasi Pendidikan. Yogyakarta: Ar-Ruzz Media.

Triatma, I. (2016). Minat Baca Pada Siswa Kelas VI Sekolah Dasar Negeri Delegan. E-Jurnal Prodi Teknologi Pendidikan, V Nomor 6 (Teknologi Pendidikan), 166-178.

Wachidah, L., Suwignyo, H., \& Widiati, N. (2017). Potensi Karakter Tokoh dalam Cerita Rakyat sebagai Bahan Bacaan Literasi Moral. Jurnal Pendidikan: Teori, Penelitian, dan Pengembangan, 2(7), 894-901.

Wahyuni, S. (2019). Menumbuhkembangkan Minat Baca Menuju Masyarakat Literat. Diksi, 16(2), 179-189. https://doi.org/10.21831/diksi.v16i2.6617

Waladiyah, N. (2018). Pengembangan Media Explosion Box Tumrap Kawasisan Nulis Teks Geguritan Siswa Klas VII SMPN 26 Surabaya Taun 2017-2018. Baradha Jurnal Mahasiswa Unesa, 1(1). Retrieved from http://jurnalmahasiswa.unesa.ac.id

Wulananda, R., Saryono, D., \& Suwignyo, H. (2016). Estetika Profetik Novel Muhammad: Lelaki Penggenggam Hujan Karya Tasargo G. K. sebagai Sumber Pendidikan Karakter. Jurnal Pendidikan: Teori, Penelitian, dan Pengembangan, 1(7), $1350-1363$. 